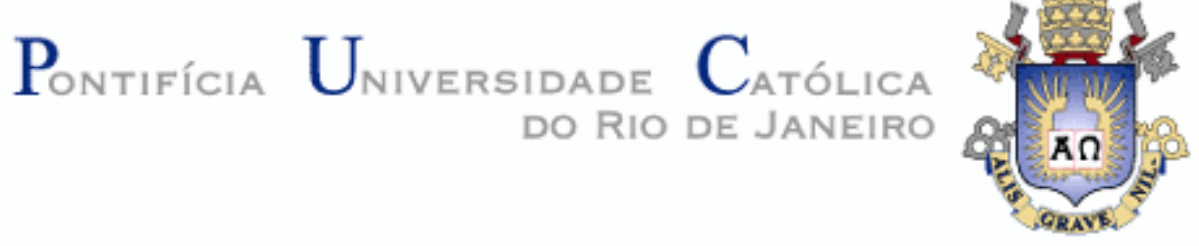

Marcia Olivé Novellino

Images in a Textbook of English as a Foreign Language: Perceptions of Students and Teacher

Orientador: Prof. Barbara Jane Wilcox Hemais

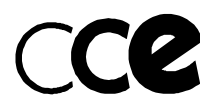

COORDENAÇÃo

CENTRAL DE

EXTENSÃO

Rio de Janeiro

2005.1 


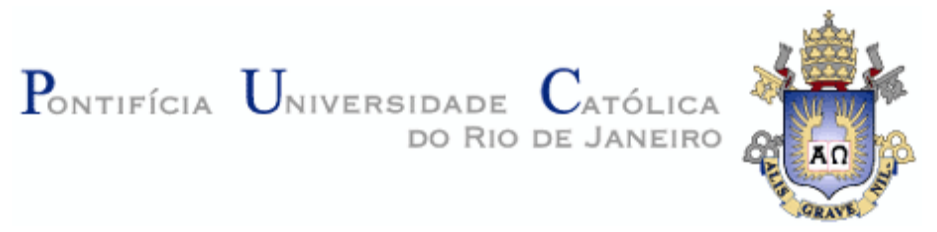

\section{DEPARTAMENTO DE LETRAS}

Pós-Graduação Lato Sensu em Língua Inglesa

Images in a Textbook of English as a Foreign Language:

Perceptions of Students and Teacher

Marcia Olivé Novellino

Orientadora: Profa. Dra. Barbara Jane Wilcox Hemais 


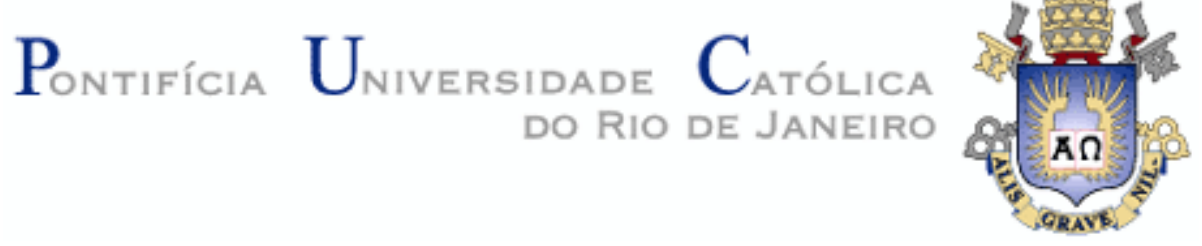

Marcia Olivé Novellino

Images in a Textbook of English as a Foreign Language:

Perceptions of Students and Teacher

Monografia

Monografia apresentada ao Programa de Pós-Graduação em Letras da PUC-Rio como requisito parcial para obtenção do título de Especialista em Letras.

Orientadora: Profa. Dra. Barbara Jane Wilcox Hemais

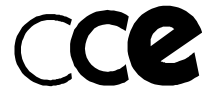

COORDENAÇÃo

CENTRALDE
EXTENSÃO

Rio de Janeiro

2005.1 
Departamento de Letras

\author{
Marcia Olivé Novellino
}

\title{
Images in a Textbook of English as a Foreign Language: \\ Perceptions of Students and Teacher
}

\section{Monografia}

Monografia apresentada ao Programa de Pós-Graduação em Letras da PUC-Rio como requisito parcial para obtenção do título de Especialista em Letras. Aprovada pela Comissão Examinadora abaixo assinada.

Orientadora: Profa. Dra. Barbara Jane Wilcox Hemais

Examinadora: Profa. Maria Isabel Cunha 
Todos os direitos reservados. É proibida a reprodução total ou parcial do trabalho sem autorização do autor, do orientador e da universidade.

\section{Marcia Olivé Novellino}

Graduada em Língua e Literatura Inglesas pela PUC-São Paulo em 1982. Tem atuado como professora de língua inglesa em diversas instituições de ensino e empresas. Seus interesses são o estudo de multimodalidades e multiculturalismo na sala de aula e em livros pedagógicos. 
Para meus amados filhos, Gabriela e Felipe, que compreenderam e aceitaram as minhas ausências.

Para Marcos, meu marido querido, que me incentivou e me apoiou em todos os momentos.

Para minha mãe, Leyde, que me deu suporte para que eu realizasse mais esse sonho 


\section{Agradecimentos}

A realização desse trabalho se deve ao apoio e incentivo que recebi de meus familiares, amigos, professores e instituições. Agradeço:

* A Deus, que me iluminou e conduziu;

* À minha orientadora, Barbara Hemais, por sua paciência e orientação;

* Às professoras Inés Kayon de Miller e Maria Isabel Cunha, pelo estímulo e carinho ;

* A meus professores da especialização, cujos conhecimentos compartilharam comigo;

* À professora Alba, cujo apoio e interesse foi fundamental para esse trabalho;

* À direção da Escola Alemã Corcovado, por autorizar minha pesquisa e me apoiar;

* À turma 7R/ 2005 do EAC, que com muito entusiasmo se interessou em contribuir para a realização dessa pesquisa;

* À minha amiga Elizete, que me estimulou a perseguir esse sonho;

* Ao meu marido, Marcos, que me possibilitou essa realização, me apoiando e incentivando com carinho;

* Aos meus filhos, Gabriela e Felipe, por terem compreendido minhas ausências e me apoiado com seu amor;

* A minha mãe, Leyde, que permaneceu sempre ao meu lado;

* À minha Tia Lygia, cuja fé me contagiou;

* E a todos que indireta ou diretamente me possibilitaram a finalização desse trabalho. 


\section{ABSTRACT}

This paper examines the use of visuals in textbooks and their appeal to students and teachers. It also analyses how visual tecniques help students understand the activities presented in the book. An analysis of icons used for managing the lessons was carried out in a textbook of English as a Foreign Language. Teacher's and students' perceptions were examined through a questionnaire. This paper discusses the teacher's and students' perceptions of the function of visual elements in the textbook used in their course. 


\section{Table of Contents}

1. Introduction

2. Terms and concepts

2.1. Author

2.2. Icons

2.3. Coloured Marker

2.4. Picture of Scrap Paper

2.5. Drawing

2.6. Thinking Bubble

2.7. Contrast

3. The Method

3.1. Setting 16

3.2. The Book 16

3.3. Selection of Parts

16

3.4. Procedure for Questionnaire

4. Results and Discussion

4.1. Question 1 - Icons

4.1.1. 初

4.1.2. 篮

20

4.1 .3

21

4.1.4. 究䟚

4.1.5.

4.1.6. :

4.1.7. Teacher's perceptions of how useful the icons are for her classes

4.2. Question 2 - Yellow Boxes 26

4.3. Question 3 - Scrap Papers 27

4.3.1. Image A 28

4.3.2. Image $B \quad 31$

4.3.3. Image C 33

4.4. Question 4-Coloured Markers 34 
4.5. Question 5 - Drawings 35

4.5.1. Learners' statements about whether the drawings 36 help them understand what to do and how

4.5.2. Learners' opinion on which is easier for them to understand: the drawings or the words

4.6. Question 6 - Thinking Bubbles

$\begin{array}{ll}\text { 5. Conclusion } & 40\end{array}$

6. Bibliography 43

7. Appendix 44

Appendix A - Teacher's Questionnaire

Appendix B - Student's Questionnaire

Appendix C - Analysis of the Students' Questionnaire 


\section{INTRODUCTION}

The first contact children have with books is through images. But from the moment they start to learn how to read and write in school, the amount of written texts increases in books and the number of images starts to decrease. (Kress and van Leeuwen, 2000). One question to consider is that if images have what seems to be an important role in the way children experience the world, why does the amount of images seem to decrease compared to the amount of writing that seems to increase as learners become older? According to Kress and van Leeuwen ( 2000:15), " texts produced for the esrly years of schooling are richly illustrated, later on visual images give way to a greater and greater proportion of verbal, written text". Another question is: why does writing gain more prestige despite the abundance of images we deal with in our day-to-day and professional life? Even though researchers have observed (Kress and van Leeuwen, 2000) the increase in the use of images in textbooks, it seems that they are still far from having the same importance or understanding as writing has in our western world. If images were once so important in people's childhood why don't they seem to be considered as important when people grow older? The present paper is concerned with the occurence of images in a textbook, and, more importantly, the teacher's and students' awareness and understanding of the meanings of the images.

In recent decades, visual communication has become more prominent not only in newspapers, advertisements, magazines, but also in textbooks. English Language textbooks have followed this trend, with the inclusion of varied images in the lessons, therefore a parallel can be drawn between textbooks and texts in general. "In contemporary texts the majority of the space is given to images and they have a significant role together with language in communicating the essential information about the topic" (Kress 2000, cited in Unsworth 2004 : 10). Considering what Kress stated above, the first question I considered when I chose this topic of study was whether the images were being used only to illustrate the lessons, and thus make the book more appealing to students and teachers or whether there were any other functions for the use of images in 
textbooks. The second question that arose was whether the students and the teacher who took part in the research noticed the different functions of the images in the book and how they perceived certain visual elements.

The analyses of the images of the English Language textbook Green Line $2-N e w$ is based on the study of images that Kress and van Leeuwen present in the book Reading Images - The Grammar of Visual Design (2000), and on the analysis of techniques and visual concepts that Dondis (2000) presents in her study of visual syntax.

Kress and van Leeuwen make an analogy between the grammar of language and what they call the grammar of visual design. It does not mean that language and visual structures are alike. Their relation is much more general, but both involve some kind of structure, rules to follow and a social construct. Language realizes meanings as linguistic structures while visual communication realizes meanings through visual structures. The authors point to "different interpretations of experience and different forms of social interaction" (2000:2). Some things can be said visually and verbally, other things can be said either verbally or visually, and there are times when they can be said to be partly visual and partly verbal." But even when they can be 'said' both visually and verbally the way in which it will be said is different."(2000 : 2)

Kress and van Leeuwen suggest that the same way people learn how to write and read, they should learn about visual structures, and therefore a "move towards a new type of literacy" (2000 : 15), which is visual literacy, should be conducted.

Magazines, newspapers, and advertisements have always made use of visuals to communicate their messages, but what is interesting is that textbooks seem to have increased the use of visuals in their materials as well, and therefore it seems that

"... educationalists everywhere have become aware of the increasing role of visual communication in learning materials of various kinds, and they are asking themselves what kind of maps, charts, diagrams, pictures and forms of layout will be most effective for learning". ( Kress and van Leeuwen $2000: 12$ ) 
Dondis argues that " to be considered verbally literate it is necessary for us to learn the basic components of written language " ${ }^{1}$ (2000:3). The same way, one should learn the basic components of visual communication that together with techniques will help create clear visual messages. For Dondis, literacy means that "a group shares a common meaning to a given information body" 2 (2000 : 3). The objectives for a visual literacy should be the same as those for written language : " build a basic system for learning, identification, creation and understanding of visual messages " 3 (Dondis, $2000: 3$ ). In "Sintaxe da Linguagem Visual " 4 , Dondis offers a general view of the basic elements that constitute "the compositional font of every type of material and visual message, besides the objects and experiences " 5 from which the concepts of colour and contrast were essential for the analysis of certain images in this research. Dondis argues that meaning in both language and visuals are important, and that

\footnotetext{
"Visual mode constitutes a whole body of data that, together with language, can be used to build and understand messages in different levels of utility, from the purely functional to the highest domains of artistic expression". ${ }^{6}(2000: 3)$
}

The objective of this paper is to see how twenty five students and their English teacher perceive the images that appear in the textbook of English as a Foreign Language used in the school and, at the same time to draw a parallel between what they perceive and the work of Kress and van Leeuwen and Dondis about the importance of looking at images as more than simply visual aids. Their studies were crucial to the support needed for the analysis in this research.

\footnotetext{
1 "Para que nos considerem verbalmente alfabetizados é preciso que aprendamos os componentes básicos da linguagem escrita..." (Dondis, $2000: 3$ ).

2 "um grupo compartilha o significado atribuído a um corpo comum de infomaçôes" (Dondis, 2000 : 3).

3 “construir um sistema básico para a aprendizagem, a identificação, a criação e a compreensão de mensagens visuais..." ( Dondis, $2000: 3$ ).

4 "Sintaxe da linguagem visual"

5 "fonte compositiva de todo tipo de materiais e mensagens visuais, além de objetos e experiências" (Dondis $2000: 3$ )

6 "O modo visual constitui todo um corpo de dados que, como a linguagem, podem ser usados para compor e compreender mensagens em diversos níveis de utilidade, desde o puramente funcional até os mais elevados domínios da expressão artística." (Dondis, $2000: 3$ ).
} 


\section{TERMS AND CONCEPTS}

With the purpose of showing the theoretical basis and the focus of analysis of this paper I will present a definition of the term author, as it will be used in this paper, and the concepts of icon, coloured marker, picture of scrap paper, drawing, thinking bubble and contrast used in the investigation in the section below.

\subsection{AUTHOR}

"Author" is defined in Collins Cobuild English Language Dictionary (pg 84) as "a person whose occupation is writing books" and "artist" (pg 70) is defined as "someone who draws, paints as a job or hobby". The word "author" will be used in this paper meaning the person or people involved in the writing and in the visual preparation of the book. On the first page of the book, there is provided a list of thirteen names of people who seem to have been responsible for the written text. On the second page, the same list is shown again, this time stating where they are from; some are from the UK and some are from Germany. A list with the names involved in the "Visuelle Gestaltung", which means "Visual Organization" in English, is also provided on the same page. Nevertheless, the researcher regards it difficult to separate the work of the people who prepare the texts and the people responsible for the visuals, first because the visuals seem to be closely connected with text and vice-versa, and second because it is difficult to know how much of an artist an author can be. Therefore, in this investigation the term "author " will be used indiscriminately meaning the author and / or the artist or illustrator.

\subsection{ICONS}

According to Dyer (1982 : 125), the 'icon' is the sign in which "the signifiersignified relationship is one of resemblance, likeness". If an 'icon' can be 
considered a 'sign', then Kress and van Leeuwen (2000:6) see signs as 'a representation of some object or entity...' W.J.T.Mitchell , in the book, Iconology: Image, Text, Ideology ( 1986: 2 ) states that “... the critical study of icons begins with the idea that human beings are created ' in the image and likeness' of their creator and culminates, rather less grandly, in the modern science of 'image-making' in advertising and propaganda". As icons are used before certain activities in every lesson of Green Line 2 - New , a selection of six icons will be part of the investigation in this paper.

\subsection{COLOURED MARKER}

The book makes use of yellow and blue markers. By "markers" the researcher means the colours the book uses in order to give special visual effect to a sentence, a clause or a number. Although boldface, capital letters and the position of paragraphs can also be considered markers, this study will concentrate on the coloured markers.

The colour yellow is used in some activities marking a whole sentence or clause. As it looks like a box, connecting all the elements of the sentence and/or clause together, it will be called "yellow box". An example of this image is presented below.

\section{listen to their music}

The number of every exercise shows a blue marker, as if a highlighter pen was used, like in the example below:

\section{The Maths book}

Dondis ( 2000: 69 ) states that colour has "a specific informative value, which is realized through the symbolic meanings attached to it." ${ }^{1}$ This concept suggests that the colours yellow and blue were not simply chosen at random.

\footnotetext{
1 "um valor informativo específico, que se dá através dos significados simbólicos a ela vinculados." (Dondis, $2000: 69$ )
} 
About the colour yellow, Dondis (2000:69) writes that this colour is the most "emotional " and that "it has great power and can be used for good advantage to express and itensify visual information." 2 The colour blue is referred to as passive and soft (Dondis, $2000: 65$ ).

Besides its reference to colours, the term "marker" also refers, in this paper, to the idea that markers bring to one's mind: "a pen with a thick tip made of felt, which is used for drawing and for colouring things." (Collins Cobiuld English Language Dictionary, 1993: 889), which is the image brought to mind when in contact with exercises that have this visual aid. This kind of marker can also be seen as representing the role of the reader. In this book, it might be a way the author finds to help the reader perceive that readers might use coloured markers to highlight parts of a text when they read.

\subsection{PICTURE OF SCRAP PAPER}

Kress and van Leeuwen (2000 : 38) say of images that they "have the function of illustrating an argument carried by the written word, that is, of presenting 'translating' the contents of the written language in a different medium". Images of pieces of paper that seem to have been torn out of a notebook or a folder are frequently used in the exercises. The author might want to make a connection with the students reality, as students not only tear off parts of their notebooks but as well cut out things from magazines and newspapers, for example. The researcher will be using the term "picture of scrap paper" when referring to this kind of image that seems to illustrate some kind of an argument in the book.

\subsection{DRAWING}

According to Wysocky (2004 : 133) drawing is "an illustration that is not supposed to look as though it were made with a camera". A camera takes photographs which, according to Wysocky (2004: 132), "brings a sense of

\footnotetext{
2 "ela tem grande força e pode ser usada com muito proveito para expressar e intensificar a informação visual".( Dondis, 2000: 69 )
} 
immediacy and 'reality' to a layout". Drawings, on the other hand, bring the image of something that is hand-made like "a picture made with a pencil, pen, crayon, etc which usually shows only the outline of something", as Collins Cobiuld English Language Dictionary defines it. The researcher will use the term "drawing" when the image that is presented resembles the ones that are hand made, as if made with a pen, coloured pencil, and so on.

\subsection{THINKING BUBBLE}

In comics it is very common to see characters' talk involved in a kind of vector called "speech balloon or speech bubble" ( Unsworth, $2004: 77$ ). Thinking bubbles or thought 'clouds' are also used but they communicate what the character is thinking. The book under study here uses this image and the researcher will refer to it as "thinking bubble".

\subsection{CONTRAST}

Dondis (2000 : 107) states that "The most efficient control for visual effect can be found in the understanding that there is a link between message and meaning, on the one hand, and visual techniques on the other " 3 . Therefore, one of the techniques used in the book to provide a special visual effect is contrast. Contrast is a powerful tool to enhance or highlight a picture. According to Dondis (2000 : 108) "... it is a way to intensify the meaning". It "unbalances, shocks, stimulates, calls the attention." "The author of Green Line-2 New makes use of this technique in the lesson analysed whenever a piece of paper is displayed on the page.

\footnotetext{
3 "O controle mais eficaz do efeito visual encontra-se no entendimento de que existe uma ligação entre mensagem e significado, por um lado, e técnicas visuais por outro." (Dondis, 2000 : 107) 4 "desequilibra, choca, estimula, chama a atenção." (Dondis, $2000: 108)$
} 


\section{THE METHOD}

\subsection{SETTING}

The researcher is an English Language teacher and has noticed that the amount of visuals, not only in English Language textbooks but also in textbooks in general, seem to have increased in recently published materials. One book, in particular, called the researcher's attention: an English language textbook adopted by a a bilingual German school in Rio de Janeiro, as part of the curriculum.

\subsection{THE BOOK}

In this school, English classes begin when students are in the equivalent to the fourth grade in the Brazilian educational system, which corresponds to the 'Gymnasien ' in the German educational system. English classes are given five days a week, with classes that last 45 minutes.

The school adopts the Green Line collection of the English Language textbook Green Line 2 - New. This book is adopted in Germany, in the schools located in the Baden-Württemberg region, and where it is used to teach English to German students, whose mother tongue is German. The instructions in the book are given in German and English.

\subsection{SELECTION OF PARTS}

As this book uses a variety of images in the lessons, the researcher decided to investigate how these images are used in this textbook. After analysing the lessons in the book, the researcher decided to investigate the user's views on the six types of images that appear in Lesson Four: icons, yellow boxes, pictures of scrap papers, coloured markers, drawings and thinking bubbles. 


\subsection{PROCEDURE FOR QUESTIONNAIRE}

The research was conducted using two different questionnaires (one for the teacher and one for the students), and an interview with the teacher was recorded so as to register her open observations on the textbook and the images. The questionnaires were different because the objective in the students' questionnaire was to see how they perceived the images in their English textbook, while the objective in the teacher's was not only to see how images were perceived but also if the teacher thought the images were useful for her classes.

In order to interview the English teacher an appointment was made at the school. The researcher explained to the teacher the objective of the research and was allowed to record their conversation on tape. The teacher talked about the book and explained that Green Line 2 - New was adopted by this school because the school followed the curriculum adopted by the schools in the Baden-Württemberg region, in Germany, which use the Greenline 2 - New textbook. Besides the interview, a questionnaire was also given to the teacher in order to see (1) whether the signs presented in the book were actually used by the teacher and (2) how and whether the teacher considered the use of visuals in this textbook important for the teaching of English. When the researcher contacted the teacher to take part in this research, and the appointment was made, the time the teacher had available was enough only to answer the questionnaire. But on the day of the appointment, the researcher had the chance to interview the teacher as well. As the teacher is usually very busy at the school, the researcher decided not to clarify some points on the teacher's questionnaire, as the researcher considered them of little relevance for this study.

The teacher consulted with the school and the students about whether they would agree to answer the questionnaire and be part of the research. Therefore an appointment was made and a questionnaire was given to each of the twentyfive students, aged about 12 years old, who are in the equivalent to the sixth grade in the Brazilian education curriculum. The questionnaire was answered during their English class at the German bilingual school. The researcher and the classroom teacher were present at the time when the students filled in the questionnaire. They were given instructions in English and Portuguese in order to avoid any comprehension problem. They were introduced to the researcher by 
their English teacher and they were told about the work the researcher was doing as her final paper. Each step of the questionnaire was clarified with the help of the researcher. They were told they did not need to write their names on the questionnaire because the researcher did not need to know that for the research, and that they did not need to talk to their peers, as what mattered was their individual view on the subject. They were also told that they would not get any grades as the questionnaire was not a test and that its objective was to see how that class perceived the images in the textbook, Green Line 2 - New . 


\section{RESULTS AND DISCUSSION}

With the purpose of illustrating the findings, this section will present and comment on some extracts that are more representative of the students' and teacher's perceptions concerning each visual aspect that was present in the six questions of the questionnaire. The language used by the students and the teacher, either in English or Portuguese, was preserved and transcribed exactly as it was written in the questionnaire. Tables with the main content of the students' answers are provided in Appendix A. The researcher considered that a table with the teacher's answers was not necessary because the teacher answers are transcribed and commented after each presentation of the results.

\subsection{Question 1 - ICONS}

The book Green Line 2 - New makes use of icons before certain activities in each lesson. A list of ten icons and their meaning in German is shown in the beginning of the book, page 2 , as follows:

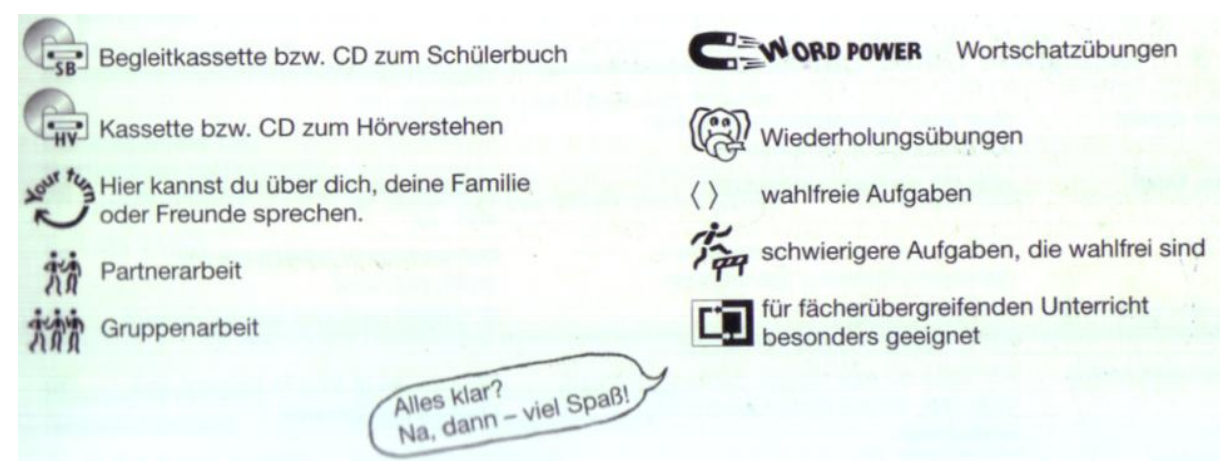

The occurence of icons before certain activities in Unit 4 in this book seems to be a way of passing on information about classroom procedures and language learning without having to rely on written language. Since in the beginning of the book the meaning of the icons is conveyed, and their images resemble their meaning, their use on the page, before certain activities, might be a way of 
helping students and/or teachers know what to do without having to read and process more written language than is already being used in the unit.

The researcher chose six of the icons that appeared in lesson Four.

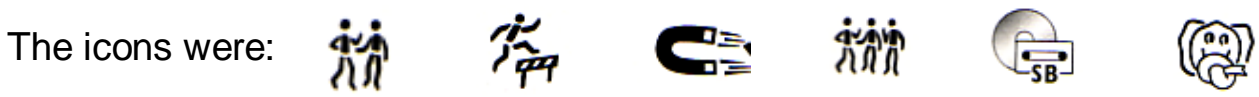

The students were requested to say whether they recognized the icons shown in the questionnaire and, for the ones they recognized, they were asked to write what they thought the icon meant. The same procedure was followed with the teacher; however, the teacher was also asked to comment on how useful these icons were for that class. This question on how useful the icons were, was not given to the students as the objective of the researcher in this study was to see how students perceived the images, and not how useful they thought the images were for them.

The students' and the teacher's opinions on the question they had in common will be commented on below. The question that only the teacher had in the teacher's questionnaire will be discussed at the end of the presentation of the results of the icon analysis.

\subsection{1. 唡}

This icon is used when the exercises suggest a pair work activity "Partnerarbeit", which means "pair work" in English.

Sixteen students referred to this icon as " trabalho em dupla " ou " pair work", which is the meaning suggested in the book for this icon. Two students said the icon meant " friends", which the image in a way suggests: two people seem to be talking as friends do. Seven students wrote they did not know or did not recognize the icon shown.

The teacher referred to this icon as an oral exercise. As the teacher is allowed to adapt each exercise to the needs of each class, she might use the activities that have this icon as an oral exercise. Pair work activities might be used by the teacher as an opportunity to give students oral exercises. 
This icon, in fact, shows two people who seem to be in a conversation. Conversations usually involve gestures, and the two people are shown as if they are moving their arms. Studies of paralanguage show that when people talk they usually need some kind of contact (eye contact, for instance), and the people in the picture seem to be looking at each other, or facing one another. Conversations usually need more than just one person, and the icon shows two people interacting, passing on the idea of a dialogue taking place . (Gumperz, 1982).

Conversations are usually performed orally, and therefore all these signs might have made the teacher think of a conversation taking place, of an oral exercise. Thus, the teacher's perception of the icon seems justified.

\subsection{2. 草}

This icon is used when the exercise it refers to is considered a challenge. It is referred to in the book in German as "schwierigere Aufgaben, die wahfrei sind" which in English means "difficult exercise, feel free to do it".

Two students stated that it meant " um obstáculo a ser superado" - an obstacle to overcome. An obstacle is something that makes one's way difficult, and this has to do with the meaning suggested by "difficult exercise". To jump an obstacle can be regarded as a challenge, something the student should overcome, not an easy thing to do, something that requires extra strength.

Sixteen students did not know what this icon meant. Five students referred to it as a physical exercise - "pular" - or sports - "praticando esportes, maratona" - and did not seem to make any connection between the image of a person jumping an obstacle and the possible meaning of what was required in the exercise. One student said the icon meant "attention", which in a way is required when one needs to jump over an obstacle. And one student referred to it as an exercise "you don't have to do, only if you want ", which is part of the explanation given by the book . 
The teacher recognized this icon as "challenge", which again refers to "difficulty", proposed by the book, but not necessarily interpreted as "difficulty" by the teacher.

For something to be considered a challenge it should offer some kind of difficulty, that must be faced in order to reach the objective. During the interview the teacher said that she is familiar with the icons used in the book. But as she is free to do the activities the way she considers best for the class, she recognizes the icon, but does not necessarily do what the icon suggests.

\subsection{3.}

This icon appears when the objective of exercise is to work on vocabulary. It means "Wortschatzübungen" or "word power". An important point worth mentioning is the use of the words "word power" that are always written in English beside this icon every time it appears.

Eleven students wrote this icon meant "word power". Nine students stated they did not know the meaning; therefore they did not recognized it as being part of their knowledge.Three students referred to the icon as a "magnet" or "imã", which is the immediate literal idea that comes to one's mind when looking at the image of the magnet. One student referred to it as "your turn" . And another student wrote it meant "puxando idéias", which is not the meaning the book wants to convey, but which is a possible connection between the image of the magnet attracting - "puxando" - objects or "idéias", as the student wrote.

The teacher showed she is familiar with this icon, saying that it means "word power" and "vocabulary", which is in fact the meaning given in the book.

This icon, without "word power" written next to it, does not seem to be recognized by the students. The reason might be that the image of the magnet does not refer to vocabulary, which is what this icon refers to: vocabulary excercise. The students who recognized the icon probably remembered the words word power written in the book beside this icon. 


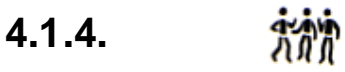

The icon above appears before activities the book suggests, to be done in groups. It is referred to as "Gruppenarbeit" which means "group work" in English.

Seventeen students recognized the icon as "trabalho em grupo", that is group work, which is exactly the meaning provided for this icon in the book. Six students did not recognize it and said they did not know its meaning. And two students referred to it as "friends", an idea that can be drawn from the image of three people that seem to be talking, which is the idea one might have of friends.

The idea of group work presented for this icon in the book is shared with the teacher, who referred to it using the same words: "group work".

\subsection{5.}

The meaning for this icon given in the book is "Begleitkassette bzw. CD zum Schülerbuch" which in English means "a tape and a $C D$ accompany the student's book". It is used in activities where a tape or a CD is required.

Nineteen students recognized the image as a listening activity using a tape or CD. Three students wrote that the book comes with a CD, which does not necessarily involve a listening activity, but suggests only that there is a CD. Three students did not know what this icon stood for.

As it is probably used for playing the tape in the classroom, the teacher recognized this icon as "tape exercise". 


\subsection{6.}

This icon means "Wiederholungübungen" which corresponds in English to "repetition exercise". It is applied when the students are required to work over a grammar point, paying special attention and keeping in mind whatever has been taught in the lesson. It appears in the last part of the lesson. Repetition carries the meaning of doing what "you have already done" (Collins Cobuild English Language Dictionary, 1993 :1226), and in fact the students are not required to do the same exercise again, but to do a different exercise that goes over a grammar point to check how much they have learnt. In fact, the word "review", which is defined in Collins Cobuild Dictionary as "a situation or series of events you think about or talk about, in order to understand them better", can be applied to the meaning of this icon, without changing the meaning of "Wiederholungübungen", given in the book.

Thirteen students stated they did not know the meaning of this icon. Four students referred to it as a difficult exercise - "exercício difícil", which does not seem to have much in common with the idea of "reviewing" or "repeating" suggested by the book. Reviews do not need to be difficult, since they are a way of helping students internalize better what has been taught. Three students interpreted the icon as a dog - "cachorro" - and elephant - "elefante", not connecting it to any special meaning in the book, but only to the image the icon shows. Two students interpreted the icon as a review -"revisão", which seems to be the idea the book wants to convey for this icon. One student wrote it was a tongue twister - "trava língua" - and this student might have come to this conclusion because of the twisted trunk shown in the icon. Another student referred to the meaning of the icon as a "pronunciation exercise " and another as silent work - "trabalho em silêncio".

The teacher wrote that this icon meant "something to remember", which in a way might have a connection with "review". One can only remember something that has already been done, and one can only review or repeat something that has already been done. So in this way the word "remember", used by the teacher, and the words "review" and "repeat", given as possible translations for "Wiederholungübungen", are connected. 
The idea of going over something, reviewing or repeating it might be seen as something that should be remembered and learnt. The elephant is known for its memory and, therefore, a connection to what seems an elephant with a twisted trunk in the image of the icon, can be made. Nevertheless, it seems that this idea is not shared by most of the students, as most of them failed to recognize it. The image of this icon and its meaning do not seem to be clearly understood by the majority of the students of this class.

\subsubsection{Teacher's perceptions of how useful the icons are for her classes}

The questionnaire also had room for the teacher's perceptions of how useful she considered these icons for her classes. This question was not given to the students in their questionnaire because at the time of this study, the researcher wanted to focus on how the students perceived the images of the icons, and not on the usefulness of the icons for the students.

The teacher explained that these icons are not useful for her because "before doing the exercise I have already thought on the way I want to do it. The icons serve as a stimulus as to how it could be done."

The teacher shows that she is aware of the existence of icons placed before certain activities, that she knows that they mean something, and that the meaning is given in the beginning of the book. She also knows she is free to choose the activity that is suitable for each class, and that the icons serve as guide lines that can be followed or not.

As an icon can be seen as sign (Dyer, 1982), Kress and van Leeuwen (2000) argue that the interest of sign makers, when they seek to make a representation of an object rises out of their cultural, social and psychological history. Their interest is focused by "the specific context in which the sign is produced" (Kress and van Leeuwen $2000: 6$ ). Therefore, context shoud be taken into consideration when choosing to use certain images. The author of the book Green Line 2 - New was propably not only influenced by their own social, cultural and historical background and interest when choosing certain icons in the book, but also considered the students' and teachers' . 
'Signs are never arbitrary, and 'motivation' should be formulated in relation to the sign-maker and the context in which the sign is produced,..." ( Kress and van Leeuwen, $2000: 7)$. Therefore the sign-makers in this book have probably based their choices of icons on the relationship of resemblance that an icon should have, like the ones that involves pair work and group work. On the other hand, the icon that refers to "review the exercise" seems to have failed in the sense that most of the students of this class do not understand it. If "In semiology motivation is...defined in terms of an intrinsic relation between the signifier and the signified." (Kress and van Leeuwen $2000: 7$ ), this icon seems to have been of little motivation to this group of learners as they apparently did not recognize any relation between the image - signifier and the meaning-signified.

\subsection{Question 2 - YELLOW BOXES}

Yellow markers are used to mark clauses or sentences in some activities in the book. In the exercise shown below the sentences marked in yellow, "yellow boxes" as they are being called here, serve as a guide for the students to do substitution drills, and at the same time, give them no opportunity to mix the chunks of words, as they have already been organized as sentences for the students. At the same time, it seems that the author wants to connect this image to the students' world, as marking in yellow certain parts of a text is a typical action a reader does, or should do to highlight what might be important.

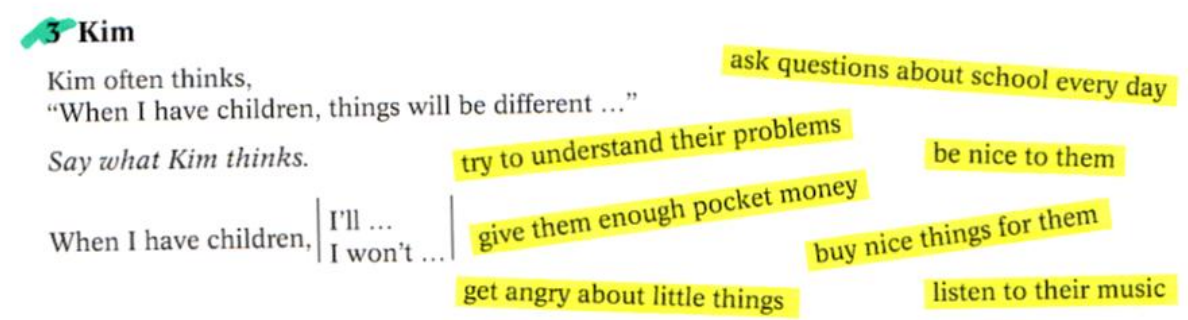

In the questionnaire the students and the teacher were required to give their opinion on why the sentences were marked in yellow. Some students' answers and also the teacher's answer are presented below.

“..para ficar bem claro quais são as opções de resposta. “

"...para ficar mais fácil ou chamar a atenção."

"Por que elas são importantes e o escritor queria destacá-las." 
"Para dar destaque às sentenças que devem ser encaixadas."

The teacher said that they "are to be included in the answers. They need to be placed in the sentence".

In the table that is in the appendix, one can see that twelve students related the yellow boxes to the exercise as an option or help for doing the activity. The teacher also connected the yellow boxes to what was required in the exercise, and saw them as parts of the answer to the exercise. Four students said that the yellow boxes were used to call their attention, because they were important, while seven other students commented that the author used them to highlight the sentences.

"Highlight", "attention" and "importance" are three of the notions that markers have for their use. Pens are used to highlight important parts of a text and are even called " highlighters" in English.

In Kress and van Leeuwen ( 2000:75 ) “... both visual structures and verbal structures can be used to express meaning drawn from a common cultural source..." . Yellow markers are often used at least in the western world, to mark any important part of a text . Learners who share the cultural idea that markers are useful tools to enhance important parts of a text will probably recognize the sentences marked in yellow - what the researcher called "yellow boxes" - with the sentences that the author wants to highlight in that specific exercise.

\subsection{Question 3 - SCRAP PAPERS}

Another kind of image found in the course book is pictures of notebook pages are used in the book, as if they have been torn off a notebook. We should bear in mind that written language is also visual and that

\footnotetext{
"A written text ,...., involves more than language: it is written on something, on some material $(\ldots)$ and it is written with something $(\ldots)$, with letters formed in systems influenced by aesthetic, psychological, pragmatic and other considerations; and with a layout imposed on the material substance, whether on the page, the computer screen or a polished brass plaque." (Kress and van Leeuwen $2000: 39$ )
} 
The author uses the concept that in order to write something, one needs a surface to write on. When inserting pieces of torn pages as images, and writing on them (grammar points, examples on how to do the exercise, and so on) the author shows that even as an image the writing is done on something. If it is not written directly on the page of the book, it is written on an image of a piece of paper. Also, the author does what a learner might do as well: tear off pages and write on torn pieces of paper.

Question number three of the questionnaire is composed of three images $A, B, C$ - and the students were asked to say why they thought the author included the images. The researcher referred to images $B$ and $C$ as "textbox images" as they contain only written language. The students' and the teacher's opinion for each of the images will be discussed below.

\subsubsection{Image A}

This is a writing exercise. Therefore, knowing that the students will need to write on something and knowing that the students will probably write on their notebook or folder page, the author uses an image of a page which seems to be part of the students' lives. The image is of a torn page, with two holes near the top. It represents a page of a folder that students might use at school, and it therefore connects the image to the students' reality. We can see that the author uses techniques that enhance the visual effect on the page of the book.

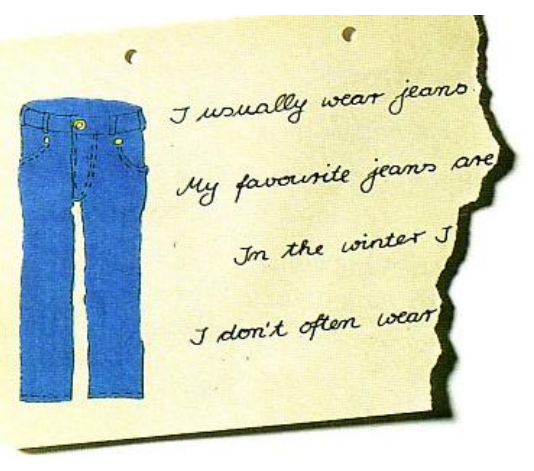


"Porque é para parecer um dever de casa sobre o que ele usa, e colocou o desenho de jeans porque é sobre o que ele fala"

"Porque quando se tem uma imagem fica mais fácil de aprender e também chama mais atenção"

"Because children often write things on small pieces of paper"

"Para o livro não ficar monótono e para dar exemplos pois assim se aprende mais rápido"

"Para você imaginar o que eles pedem"

"Porque as imagens fazem as crianças prestarem atenção no livro"

The teacher's opinion was the following "Because the lesson is about clothes, so the images serve to reinforce the reality being discussed. Stimulate"

Nine students said that the image serves as an example of what should be done in the exercise. This is one of the uses of images in textbooks: provide an example and help students understand what the written text tells them to do. Six students said that the book looks more interesting and beautiful, therefore it does not look "monotonous". This is also one of the purposes of inserting images in a textbook: enhance it, make it look attractive. Five students said that it calls their attention. Three students did not answer this question. And two students said that children use small pieces of paper, connecting the picture of a torn piece of notebok page to their use of pieces of paper.

The teacher relates it to the students' reality: students do use papers at school and sometime they tear off the pages. Jeans are well known in western society, and in Brazil, where these students live, jeans are part of their lives. Many of these students wear jeans at school, as in the school where they study, uniforms are not used.

One of the techniques used here is "contrast". According to Dondis (2000 : 119), contrast means being against something. In order to give the idea that the image of the folder page is slightly detached from the page of the book, against it, that it does not " belong " to the book, the author uses shading under the folder page that can be seen on the page of the book. The colour of the piece of folder page is not the same as the colour of the book page, which is white. Even the light that seems to come from the left side, striking the page, 
making the yellow colour of the left side "seem" lighter than it looks on the right side, creates the shade, and causes a special effect on the image. This attracts the attention of the reader.

Kress and van Leeuwen (2000) state that people who share the same cultural world might express themselves and interact visually and verbally based on the same background knowledge. The author of Green Line 2 - New seems to have in mind that students who study English with this book probably use folders, with holes on the page, usually handwrite the exercises, and use coloured pencils in their drawings.

The selection of a type of printing that looks as though it has been written by hand shows that the author might be employing "a major visual strategy" (Wysocky $2004: 127$ ), and that the author is probably aware of its effect on the reader. The activity asks the students to write a list in their folders of which types of clothes they know in English. The picture makes the connection between the written language that provides instructions and the desired format the exercise should have in the end. The book asks the students to draw a picture of a piece of clothes, handwrite and follow the written instructions given. The students are also requested to draw pictures of clothes they prefer to wear. An example of what the drawing and the written language should be is provided in the visual.

A connection between written language and visual language can be found in Kreuss and van Leeuwen (2000 : 38): "Images have the function of illustrating an argument carried by the written word, that is, of presenting 'translating' the contents of the written language in a different medium. "

In this activity the connection between the written information of what the students are supposed to do is "translated" in the the visual provided to help them visualize the activity. Even the type of writing in the picture (handwriting) is of importance as it is a writing activity and the students are expected to handwrite their preferences in terms of clothing . 


\subsubsection{Image $B$}

The next activity shows a picture of what seems a piece of paper that has been torn out of a notebook. It contains the grammar point that the authors would like students to be notice and that students will need when doing the exercise the picture refers to.

1 The play

Put in 'will' or 'won't'

1. The drama group .... act their play next week.

2. A lot of people be there.

3. All Robert's and Jenny's friends ... come, of course.

4. The Penroses ... bring Mark with them, too.

5. David hopes Mark ... be scared of the ghost!

6 . Jenny is sure everyone ... like the play.

7. But Robert thinks people laugh at the wrong time.

8. Mrs Mason, the drama teacher, hopes Robert and his friends w. feel too nervous!

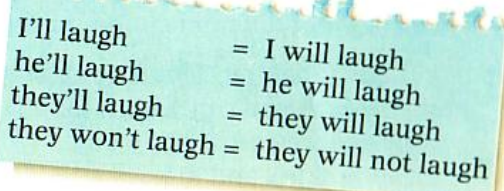

The questionnaire asked the students and teacher to focus on the image of the piece of paper, and think of a reason for the author to have included it.

"Because children often write things on small pieces of paper."

"O quadro do lado dá dica de como usar o will ."

"Para dar exemplos que deveriam ser usados no exercício e no resto de sua vida."

"Para a gente ver como fica as abreviações. E nesse papel a gente presta mais atenção do que se estivesse num texto."

"To make the book beautiful and organized."

"O papel é tipo um lembrete das coisas importantes."

The teacher said that "the boxes are to show the full extension of the verb. Show the contraction. Explain."

Nine students said that the textbox image gives an example of what they are supposed to do; it gives them giving an example and helps with the exercise. 
Again, images are connected with the written text and provide an efficient means of helping students confirm their understanding of the written text. Seven students said that the image serves as a reminder for them and that they also use reminders by tearing off pieces of their notebook pages. The connection with the students' reality seems to be part of the choice of images in this text book. Four students stated that the purpose of the image is to gain their attention. Two said the image makes the book more beautiful, organized ,and three did not answer this question.

As suggested by Widdowson (1979: 174) "the reading activity cannot be seen simply as a reaction to the meanings in a text. It is instead an interaction between writer and reader mediated through the text ". The author of Green Line 2- New plays on what seems to be common shared knowledge that some students in some situations tear off pages of their notebooks for a number of reasons. With the purpose of interacting with the students, bringing the text closer to their reality, the author chooses an image that the students will probably recognize as part of their reality. The connection between the author and the students can be established if both parts share the same background knowledge of what a page torn off a notebook is like. "Visual communication is always coded. It seems transparent only because we know the code already" (Kress and van Leeuwen, $2000: 32$ ). Therefore it is important to point out that the author of this book seems to be aware that students doing this activity will be able to understand the code - the image of a torn page.

It is also important to notice the layout of the image of the 'torn page' in the book. The image is not straight, but with an angle that differs from the layout of the activity; and the colour blue contrasts with the white colour of the page. Also, the light that seems to come from the left side of the image makes a shade on the page of the book, producing an effect on the book page that ends up calling the reader's attention. Dondis $(2000: 121)$ suggests that contrast should be used in visual composition to attract attention. 


\subsubsection{Image $C$}

The same process of highlighting is used in the activity shown below.

b) Listen to these words.

Make two lists and put the words in the list.

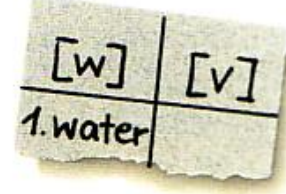

The answers were quite similar to the ones given for image B.

"To make the book beutiful and organized."

"Ele está mostrando que é para fazer uma tabela com as palavras que a gente escutou para saber se é caso de w ou v. "

"Para se explicar como se tem que fazer, ele deu um exemplo."

"To make the book more beautiful and organized."

But the number of students who said that the image was used to provide an example of what to do was higher: eighteen. As it is an exercise where the students are supposed to identify the two sounds $W$ and $V$, the information given in the image seems very limited as little is needed to understand what to do during the listening. One student said that it makes the book more beautiful and organized, two that it attracts their attention, and four did not answer this question.

The teacher did not answer this question. As the researcher did not had the opportunity to clarify this point with the teacher, the researcher imagined that she did not answer this question because her answer might have been the same as the one gave for image $B$, or maybe because she forgot or did not understand she should answer it as well.

This time the image of the paper used is not the one that resembles a student's folder page or a page torn out of the student's notebook. It is a small piece of torn paper. The students are supposed to make two lists and write down the words in the list according to the $[\mathrm{w}]$ or $[\mathrm{v}]$ sound of the words the students 
will hear during the exercise. Considering that '...Images have the function of illustrating an argument carried by the written word, that is, of presenting the contents of the written language in a different medium" (Kress and van Leeuwen, $2000: 38$ ), the image used in this activity illustrates what the written language instructs the students to do. Furthermore, it is not displayed straight, differently from the instructions of the activity. It is placed at an angle and there is shade on the page of the book, as if it were placed on the page to provide extra instructions to the students.

The fact images 4.3.1, 4.3.2 and 4.3.3 are not displayed straight on the page of the book has to do with balance. One way of creating a powerful effect is by breaking the balance of the picture. According to Dondis (2000 : 32) "Balance is the strongest and firmest visual reference that human beings have" . Dondis mentions the visual polarities such as simplicity and complexity, regularity and unexpected that exist as visual options. They may cause either relaxation or tension. Whenever there is tension in an image, more attention is required and the visual stands out more strongly. By placing the visuals in an expected angle, bending them to the right or to the left , the author produced a special effect and required more of the students' attention.

\subsection{Question 4 - COLOURED MARKERS}

Blue markers appear on the number of each exercise in the lesson. Markers are frequently used to highlight a written text and colours may vary.

3 The Maths book

2 The weather tomorrow

The participants were asked to give their opinions on the reason for the blue marker on every activity number.

"Para marcar o livro e deixá-lo mais bonito."

"To locate, because then you can know fastly where the activities are."

\footnotetext{
1 "O equilíbrio é a referência visual mais forte e firme do homem. "( Dondis, $2000: 32$ )
} 
"Because we can see it better and the book looks more organized and beautiful. Also colourful."

"Para ser chamativo e ficar mais bonito."

"Para dizer que tem dois exercícios diferentes e para ficar colorido,então o livro fica mais alegre, se fosse tudo preto ficaria monótono."

The teacher said that she thought the author decided to use it " To bring to your attention of activities which need to be done. Our 'to do' list".

According to Dondis (2000: 25) “... visual solutions must be guided for its intention towards posture and meaning, through individual and cultural style“2. One cannot deny that one of the reasons for including visuals in textbooks is that they make the books more colourful and appealing. Fourteen students recognized this when they said that the purpose of using the blue marker was to make the book more "colourful and beautiful". Seven students and the teacher said that the blue marker had the function of highlighting and calling the attention. Markers have the fuction of highliting an argument; they are in fact used to "call the attention". By marking the numbers, the author makes them more salient. Kress ( 2003: 4) states that by making some parts of an image more salient "through some means - size, colour, shape, for instance -and others less salient again encourages a reading path ", and therefore helps the students focus their attention on what is important. Four students did not answer this question.

\subsection{Question 5 - DRAWINGS}

"In the early years of schooling, children are constantly encouraged to produce images" (Kress and van Leeuwen, 2000 : 15). These images are drawings that represent the world around them. Students are familiar with drawings and are able to recognize them. The book uses drawings in the exercises, like in the one below.

\footnotetext{
2 ... as soluções visuais devem ser regidas pela postura e pelo significado pretendidos, através do estilo pessoal e cultural" (Dondis, $2000: 25$ )
} 
2 The weather tomorrow

\begin{tabular}{|c|c|c|c|}
\hline & morning & afternoon & evening \\
\hline Nottingham & $E^{3}$ & 绳= & rsto. \\
\hline London & $: 0=$ & $=$ & $\sum_{i=1}$ \\
\hline Berlin & 觔 & :Q̣= & 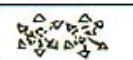 \\
\hline
\end{tabular}

Talk about the weather with a partner.

Examples:

What will it be like in Nottingham tomorrow?

- It'll be wet in the morning.

But it'll be sunny in the afternoon.

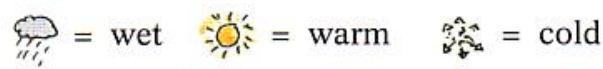

Will it be cold in Berlin tomorrow?

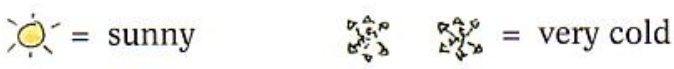

- Yes, it'll be cold there in the morning, and very cold in the evening.

4.5.1. Learners' statements about whether the drawings help them understand what to do and how

"Sim, porque mostra o que poderia estar em frases, em desenhos. Com o desenho fica mais fácil para entender".

"Yes, because learn with pictures is better than words."

"Mais ou menos,......mas serve para o autor não escrever tanto, se estivesse escrito eu ia me perder na tabela."

"Sim,.....like it would be in the news."

"No."

When asked if she thought that the drawings helped her students understand what to do and how, the teacher stated that "Yes. They're a symbolic representation of the weather which is in an international understandable language"

Twenty students said that the drawings help them understand what to do while just one student said that the drawings do not help him / her understand what to do. One student commented that "mais ou menos" and brought up the idea of drawings used in the book with the purpose of saving space.

When drawings are a representation of something that is part of reality and are made in a way that corresponds to the user's notion of an object, they seem to be understood easily. Drawings of weather representations are in newspaper and on televison weather forecasts. It has become commonplace to identify a "sun" with a sunny day, "a cloud with small oblique lines" as a rainy day, and so on. They are part of our everyday world, and people do not necessarily need a written text to understand what they mean. Kress ( $2003: 4$ ) argues that reading paths exist in images " either because the maker of the images structured that 
[ the reading path ] into the image - and it is read as it is or it is transformed by the reader -..; or... because they are constructed by the reader ."In this exercise, the drawings help the reader understand the text by using images that the students are familiar with. Students and teacher were able to 'read' the drawings using their knowledge of the images that newspapers and magazines show on weather forecasts

4.5.2. Learners' opinion on which is easier for them to understand : the drawings or the words.

"Desenhos, porque muitas vezes quando você esquece o sentido de alguma palavra a ilustração te faz lembrá-lo novamente."

"Os dois porque eu leio e entendo melhor com as imagens."

"Drawings,because they make the book more beautiful."

Twenty students answered that drawings are easier to understand.

Two students stated that words are better than drawings for them to understand . Three students mentioned both drawings and words.

The teacher also stated: "drawings- by far! "

Teacher and students share a common knowledge and recognize the drawings immediately.

The visual experience is of great importance for most people. Dondis (2000 : 6) says that this is due to its "direct informational character, the real experience proximity" ${ }^{3}$. Images bring reality closer to people, and televison and newspapers exploit this possibility of using visual data in weatherforecasts, for example. The author of the course book under study brings a real exerience closer to the students by providing them with images that they are somehow familiar with.

\footnotetext{
3 "caráter direto de informação, a proximidade da experiência real ." (Dondis, $2000: 6$ )
} 


\subsection{Question 6 - THINKING BUBBLES}

In this exercisen no written reference is given to the fact that the character is thinking. To show that, "thought clouds" or "thinking bubbles" are used.

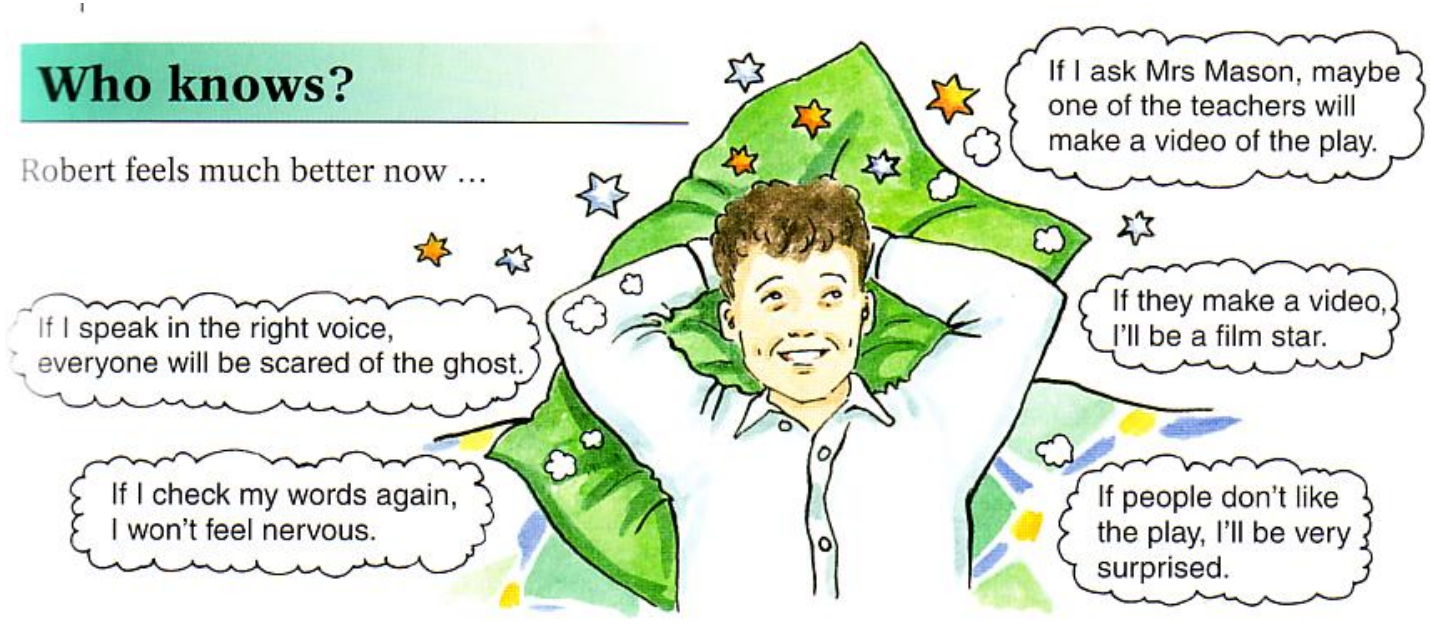

Learners' opinion on why the bubbles were used in the picture

"Porque são os pensamentos dele, e normalmente em uma história em quadrinhos ou imagens usa-se nuvens de pensamentos."

"É usado para mostrar que ele está pensando, sonhando e não falando."

"Because they are used in comics, then they are 'famous'."

"Porque são pensamentos e em histórias em quadrinho essa" nuvens" representam pensamento."

"Significa que isso são os pensamentos dele, e também todo mundo sabe que essas nuvens significam pensamentos. $E$ como isso, você não precisa ler um texto para saber que esses são os pensamentos dele, basta olhar."

All the students referred to the bubbles as "thought clouds" or "thinking bubbles" and connected them to the way thoughts are represented in comics or in textbooks. Kress and van Leeuwen (2000:67) refer to the "thinking bubbles" as a "special kind of vector" that "can be observed in comic strips... that connect drawings of ...thinkers to their ...thought". Unsworth also refers to this kind of vector that appears in images as "thought clouds" and says it is "used to communicate what the participant is thinking" (2004: 77). 
Learners at this age in Brazil are expected to have had some kind of contact with comics, and therefore " thought clouds" or "thinking bubbles" are part of their world knowledge. Kress and van Leeuwen state that "thinking bubbles" today " increasingly crop up in other contexts too, for instance in connection with quotes in school textbooks..." (2000:67). Textbooks make use of this of vector and the students do not seem to have any problem in understanding what it conveys. The learners' familiarity with this vector is shown when they refer to it as being "famous" or "everybody knows it". This image is so widespread among these students that it seems that they easily recognize the "thinking bubbles" or "thought clouds" as being the representation of thoughts of a character. In the questionnaire one student comments that “...não precisa ler um texto pra saber que esses são os pensamentos dele, basta olhar". The meaning seems extremely clear to the students.

The teacher seemed to have had no doubts in understanding what the thinking bubbles were doing in the image, and said that the thought clouds were used "because the boy is thinking / dreaming. These are his thoughts." 


\section{CONCLUSION}

According to Kress and van Leewen (2000 : 12) "Analysing visual communication is or should be an important part of critical disciplines..." Visuals carry information and they can be more than just a decorative part in a book. The analysis of the answers the students and teacher gave in the questionnaire revealed several perceptions of the kinds of information in the visuals in Green Line 2 - New.There were high occurences of notices such as "highlight", "call the attention", " beautiful ", "colorful", "exemplify"; and "facilitates the understanding of the exercise / exemplifies" were the ones students used most. The function of visuals in a school textbook can be said to be, first of all, illustrative. But other functions of textbooks visuals are to call the students' attention to something that might be of importance or to connect the written text and the image by exemplifying what the students should do or notice.

The questionnaire showed that students and teacher perceive the images in the textbook in the following ways:

a. Visuals have a function of making the textbook more attractive and colourful. This is the function that students and teacher perceive when they say that images make the textbook more beautiful and fun.

b. Visuals have the function of connecting an image to a written text. They provide examples, help students understand the exercise, and 'translate' the written contents into a visual medium. Students and teacher noticed this function, and they referred to it by saying that the image exemplifies and facilitates the understanding of the exercise in the book.

c. Students perceived techniques used to attract their attention such as colours and contrast. Whenever they said that an image calls their attention it is because the techniques make the image more noticeable.

d. Visuals have the function of highlighting an argument. Coloured markers enhance parts of a text and numbers in the textbook. Students and teacher show they perceived this effect when they answered that the marker calls the attention. 
e. Visuals also provide a rest for the eyes. A page with only written language may be tiring for the students. When saying that an image makes the textbook less monotonous, students mean that the textbook looks more interesting when there are images to rest the eyes on.

f. Visuals have the function of representing the world outside. The drawings connect the image to the students' and teacher's world. They have been familiar with drawings since they were small. The table with drawings related to the weather forecast, for example, uses elements that are part of their life just as magazines and newspapers show weather forecasts with maps.

g. Some images are so well known by students and teacher that no written language is needed to provide the meaning. The use of "thinking bubbles" is an example of an image that is so transparent that the students and teacher do not need any written explanation for it.

h. The analysis also suggests that icons need to be carefully chosen. They might be very easily understood when students and teacher not only know their meaning but also are able to recognize them as icons. Context is a factor in the understanding of visuals as was the case when students had no problems recognizing "pairwork" and "group work" because they were familiar with the images of people interacting. The image for the "review exercise", however, which showed what seemed to be an elephant, was quite difficult for students to guess. It seems that the idea that elephants have a good memory was not part of the students' world knowledge. The students had also difficulty recognizing the icons that meant challenge and word power, as the images these icons showed (a person jumping over an obstacle for the icon meaning challenge, and the magnet for the icon meaning word power) did not have a close relation to what they actually meant.

In order to use images effectively it is important for the author to not only share the students' social background but also to know the many techniques that will help them to build their visual competence. Visuals are an important means of communication. Kress and van Leeuwen (2000:13) argue that they fulfill two functions: " ... a function of representing ' the world around and inside us ' and ... a function of enacting social interactions as social relations". It does not matter whether one is involved in an oral conversation, making an 
advertisement , writing a novel, or playing a music instrument. We are " doing something to, or for, or with others in the here and now of a social context" (Kress and van Leeuwen , $2000: 13$ ).

Finally, visuals and writing have much in common for learners of English, in this study. "Writing is a form of visual communication" (Kress and Van Leeuwen, 2000 : 15). Writing is essential for the society we live in, and therefore in order to master it we must learn all that is necessary to be considered a literate person and be able to use written language successfully. The same applies to visuals. As Kress and van Leeuwen state (2000), visuals cannot be seen as a domain of specialists or on the other hand disregarded. Visuals are a part of modern literacy. 


\section{BIBLIOGRAPHY}

ASHFORD, S. et al. Green Line 2- New. Stuttgart: Ernst Klett Verlag, 2002

BLOOR,T.; BLOOR, M. The Fuctional Analysis of English: A Hallidayan Approach. London: Arnold, 1995.

COLLINS COBUILD English Lnguage Dictionary. London: HarpersCollins Publishers, 1993

COOK, G. The Discourse of Advertising. London: Routledge, 2001.

DONDIS, D.A. A Primer of Visual Literacy.Tradução Camargo, J.L. São Paulo: Martins Fontes, 2000.

DYER,G Advertising as Communication. Bury St Edmund : St Edmundsbury Press, 1982.

GUMPERZ, J. J. Language and Social Identity.Cambridge: Cambridge University Press, 1982.

KRESS,G. Literacy in the New Media Age. London: Routledge, 2003.

KRESS, G.; VAN LEEUWEN, T. Reading Images: The Grammar of Visual Design. London: Routledge, 2000.

Multimodal Discourse: The Modes and Media of Contemporary Communication. London: Arnold, 2001.

MINISTÉRIO DA EDUCAÇÃO. Programa Nacional do Livro Didático para o ano de 2002.Brasília: Fundo Nacional de Desenvolvimento da Educação, 1999

MITCHELL, W.J.T. Iconology: Image, Text, Ideology. Chicago: The University Press of Chicago, 1986.

UNSWORTH, L. Teaching Multiliteracies Across the Curriculum: changing contexts of text and image in classroom practice. New York: Open University Press, 2000.

WIDDOWSON, H.G. Explorations in Applied Linguistics, Oxford: U.K. : Oxford University Press, 1979.

WYSOCKI, A.F. The Multiple Media of Texts: How Onscreen and Paper Texts Incorporate Words, Images, and Other Media. In Bazerman, C and Prior, P. What Writing Does and How it Does It , New Jersey: Lawrence Bazerman Associates, 2004. 


\section{Images in Cousebooks}

I am doing a study of images in English coursebooks for my final paper, and your help will be of great value for my research. The images have been taken from Green Line New 2

\section{$\underline{\text { T-Questionnaire }}$}

1. Do you recognize the icons below ? For the ones you recognize, write next to them what they mean to you.

\begin{tabular}{|c|c|}
\hline 1. & 积 \\
\hline 2. & 際 \\
\hline 3. & $C=$ \\
\hline & 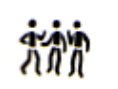 \\
\hline & $\overbrace{\mathrm{SA}_{\mathrm{SB}}}$ \\
\hline & 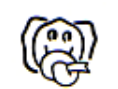 \\
\hline
\end{tabular}

How useful are these icons for your classes?

2. Look at the activity below. Why do you think the sentences are marked in yellow? Write your answer on the lines provided.

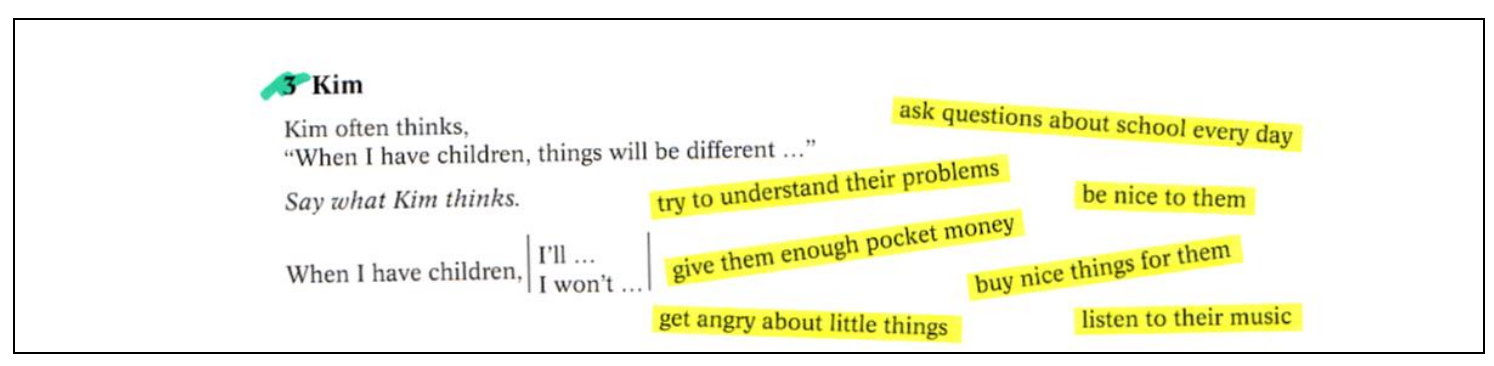


3. Why do you think the author decided to include the image in $A$ and text boxes in $B$ and $C$ ? Use the lines below the images to write your answer.

A

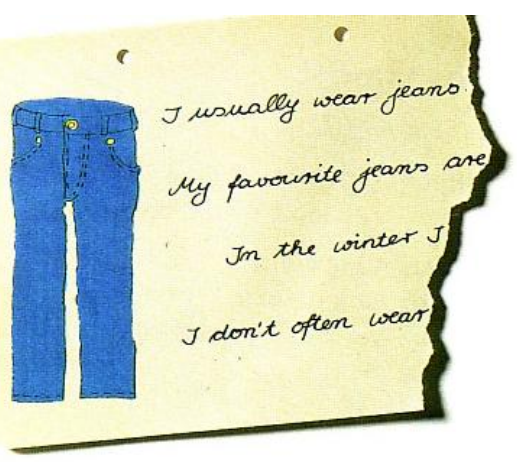

B

1 The play

Put in 'will' or 'won't'.

1. The drama group a... act their play next week.

2. A lot of people be there.

3. All Robert's and Jenny's friends ... come, of course.

4. The Penroses ... bring Mark with them, too.

5. David hopes Mark ... be scared of the ghost!

6 . Jenny is sure everyone ... like the play.

7. But Robert thinks people. laugh at the wrong time.

8. Mrs Mason, the drama teacher, hopes Robert and his friends w. feel too nervous!

C

b) Listen to these words.

Make two lists and put the words in the list.

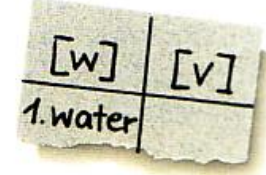


4. Have you noticed the blue marker on every activity number?

Why do you think the author decided to use it ?

5. Look at the exercise about the weather.

\section{The weather tomorrow}

\begin{tabular}{|c|c|c|c|}
\hline & morning & afternoon & evening \\
\hline Nottingham & $\sum_{3}$ & :0́ & 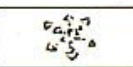 \\
\hline London & $\therefore=$ & $=0$ & $\prod_{\pi}$ \\
\hline Berlin & sos & $: 0=$ & 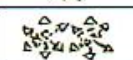 \\
\hline
\end{tabular}

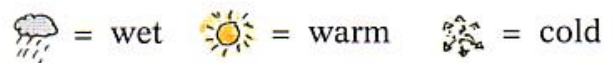

;Ó, = sunny
Talk about the weather with a partner.

Examples:

What will it be like in Nottingham tomorrow?

- It'll be wet in the morning.

But it'll be sunny in the afternoon.

Will it be cold in Berlin tomorrow?

- Yes, it'll be cold there in the morning, and very cold in the evening.

a. Do you think the drawings help your students understand what to do? How?

b. Which do you think is easier for your students to understand: the drawings or the words? 
6. Look at the picture below. Why are the bubbles used in the picture ?

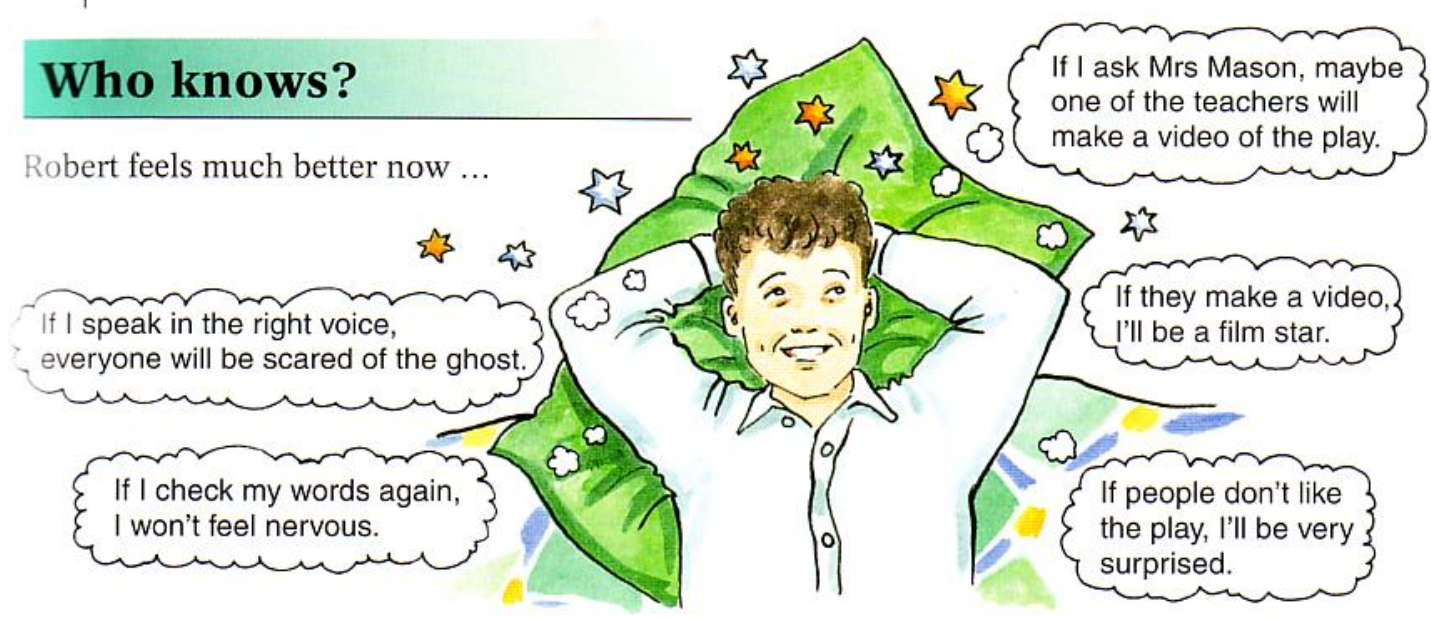

I would like to thank you very much for taking the time to answer this questionnaire and help me with my research. 


\section{Images in Cousebooks}

I am doing a study of images in English coursebooks for my final paper, and your help will be of great value for my research. The images have been taken from Green Line New 2

\section{S-Questionnaire}

1. Do you recognize the icons below ? For the ones you recognize, write next to them what they mean to you.

\begin{tabular}{|c|c|}
\hline 1. & 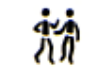 \\
\hline 2 . & \\
\hline 3. & $\sigma=$ \\
\hline 4. & 额初 \\
\hline & $\overbrace{C_{\mathrm{SB}}}$ \\
\hline & 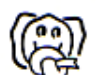 \\
\hline
\end{tabular}

2. Look at the activity below. Why do you think the sentences are marked in yellow? Write your answer on the lines provided.

\begin{tabular}{|c|c|c|}
\hline \multicolumn{3}{|l|}{$3 \mathrm{Kim}$} \\
\hline \multicolumn{3}{|c|}{$\begin{array}{l}\text { Kim often thinks, } \\
\text { "When I have children, things will be different ..." }\end{array}$} \\
\hline Say what Kim thinks. & try to understand their probl & be nice to them \\
\hline \multirow[t]{2}{*}{ When I have children, $\begin{array}{l}\text { I'll ... } \\
\text { I won't ... }\end{array}$} & give them enough pocket in & things for them \\
\hline & get angry about little things & listen to their music \\
\hline
\end{tabular}


3. Why do you think the author decided to include the image in $\mathbf{A}$ and textbox images in $\mathbf{B}$ and $\mathbf{C}$ ? Use the lines below the images to write your answer.

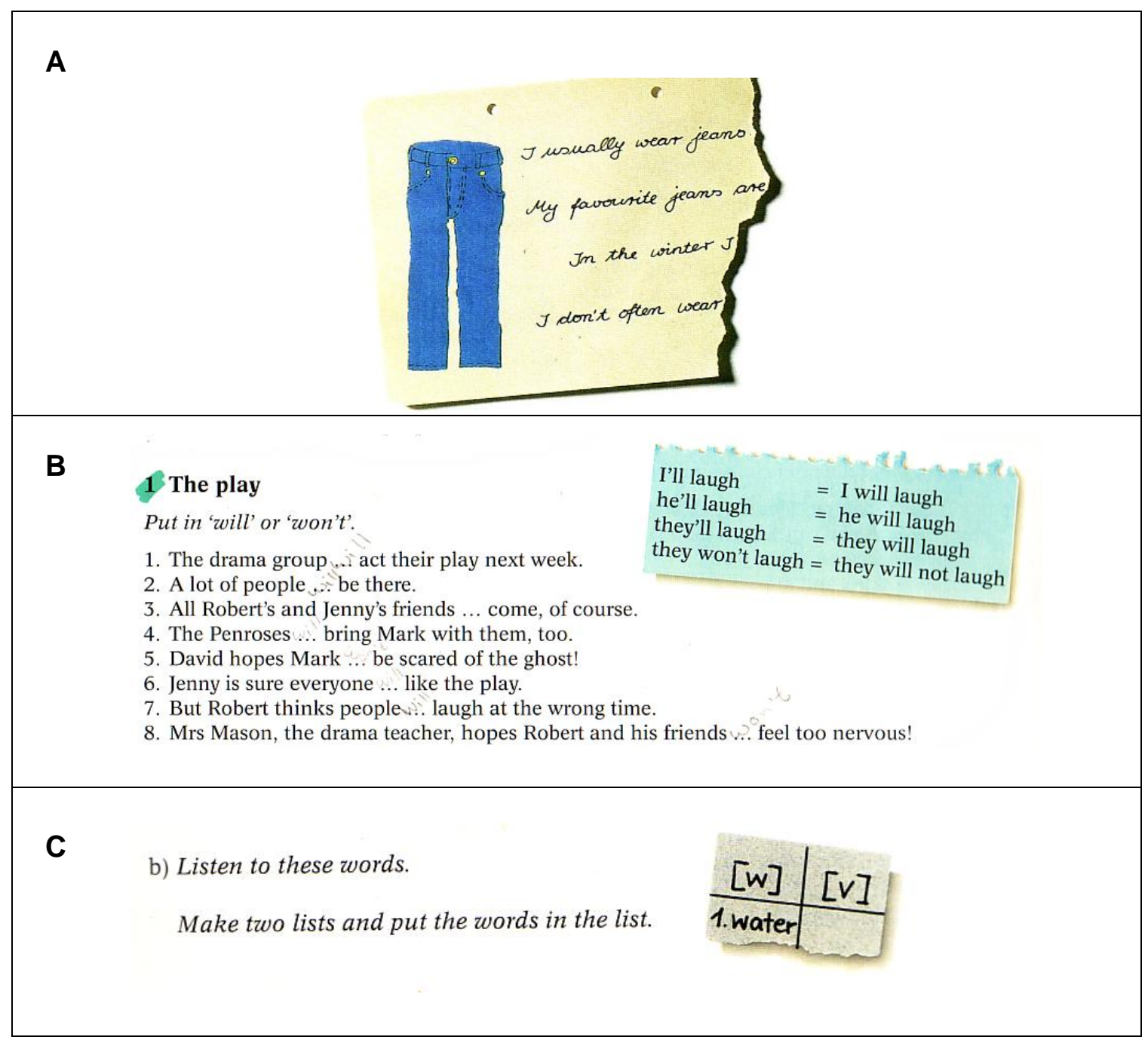

A

B

C 
4. Have you noticed the blue marker on every activity number? Why do you think the author decided to use it?

5. Look at the exercise about the weather.

\section{The weather tomorrow}

\begin{tabular}{|c|c|c|c|}
\hline & morning & afternoon & evening \\
\hline Nottingham & $\sum_{3}$ & :0́ & 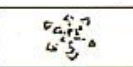 \\
\hline London & $\therefore=$ & $=0$ & $\prod_{\pi}$ \\
\hline Berlin & sos & $: 0=$ & 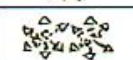 \\
\hline
\end{tabular}

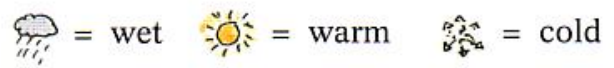

;
Talk about the weather with a partner.

\section{Examples:}

What will it be like in Nottingham tomorrow?

- It'll be wet in the morning.

But it'll be sunny in the afternoon.

Will it be cold in Berlin tomorrow?

- Yes, it'll be cold there in the morning, and very cold in the evening.

a. Do the drawings help you understand what to do? If yes, How?

b. Which is easier for you to understand: the drawings or the words? 
6. Look at the picture below. Why are the bubbles used in the picture?

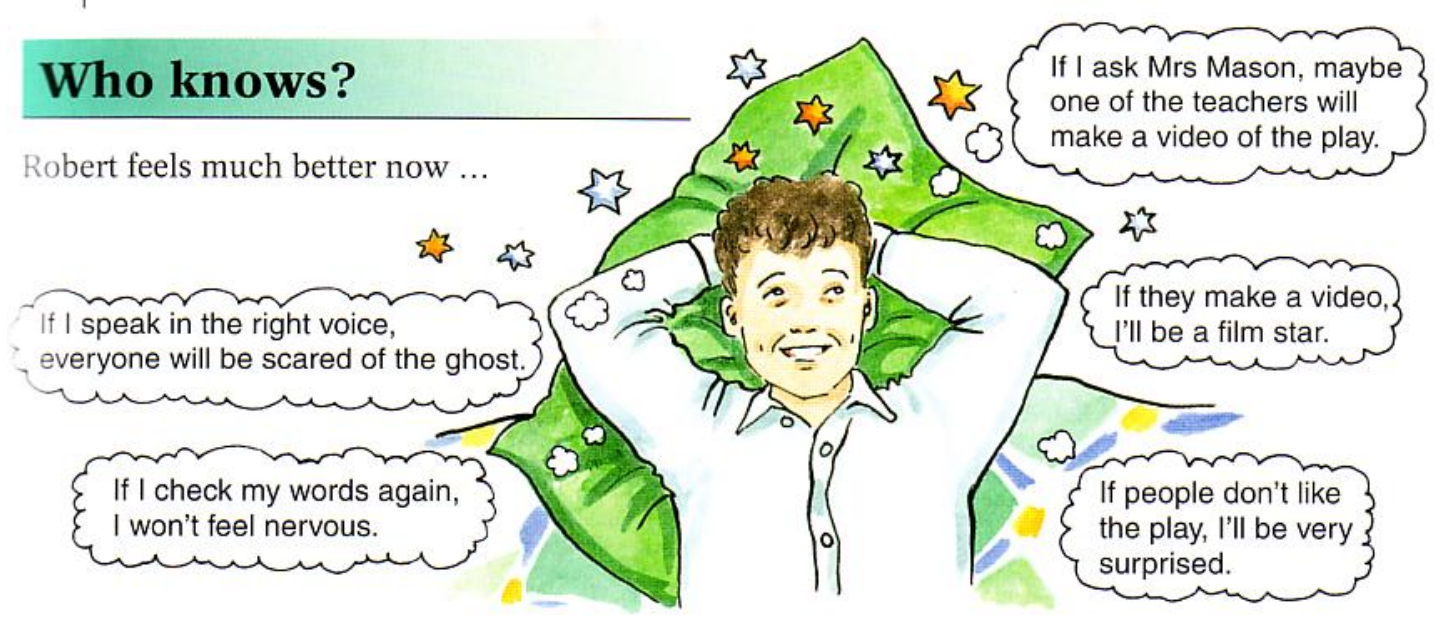

I would like to thank you very much for taking the time to answer this questionnaire and help me with my research. 


\section{APPENDIX C Analysis of the Students' Questionnaire}

Tables with the main results of the students' questionnaire is shown below.

The categories used to analyse the results were done by the researcher considering the types of answers obtained in the questionnaires.

\section{Question 1}

Do you recognize the icons below ? For the ones you recognize, write next to them what they mean to you.

1. 瓶

\begin{tabular}{|l|c|}
\hline \multicolumn{1}{|c|}{ Type of answer } & Number of students \\
\hline Pairwork & 16 \\
\hline Friends & 2 \\
\hline Did not answer/ did not know & 7 \\
\hline
\end{tabular}

2. 筱

\begin{tabular}{|l|c|}
\hline \multicolumn{1}{|c|}{ Type of answer } & Number of students \\
\hline Physical exercise/sports & 5 \\
\hline Attention & 1 \\
\hline You do not have to do & 1 \\
\hline Obstacle to overcome & 2 \\
\hline Did not answer/ did not know & 16 \\
\hline
\end{tabular}




\begin{tabular}{|l|c|}
\hline \multicolumn{1}{|c|}{ Type of answer } & Number of students \\
\hline Word Power & 11 \\
\hline Your turn & 1 \\
\hline Bringing up ideas & 1 \\
\hline Magnet & 3 \\
\hline Did not answer/ did not know & 9 \\
\hline
\end{tabular}

\section{4. संग्रां}

\begin{tabular}{|l|c|}
\hline \multicolumn{1}{|c|}{ Type of answer } & Number of students \\
\hline Group work & 17 \\
\hline Friends & 2 \\
\hline Did not answer/ did not know & 6 \\
\hline
\end{tabular}

5.<smiles>C1=[As]C=[As]C1</smiles>

\begin{tabular}{|l|c|}
\hline \multicolumn{1}{|c|}{ Type of answer } & Number of students \\
\hline Listening / CD & 19 \\
\hline Comes with a CD & 3 \\
\hline Did not answer/ did not know & 3 \\
\hline
\end{tabular}


6.

(शि:

\begin{tabular}{|l|c|}
\hline \multicolumn{1}{|c|}{ Type of answer } & Number of students \\
\hline Difficult exercise & 4 \\
\hline Dog / elephant & 3 \\
\hline Review & 2 \\
\hline Tongue twister & 1 \\
\hline Silent work & 1 \\
\hline Pronunciation & 1 \\
\hline Did not answer/ did not know & 13 \\
\hline
\end{tabular}

\section{Question 2}

Look at the activity below. Why do you think the sentences are marked in yellow? Write your answer on the lines provided.

\begin{tabular}{|l|c|}
\hline \multicolumn{1}{|c|}{ Type of answer } & Number of students \\
\hline Help / option for an answer & 12 \\
\hline Highlight & 7 \\
\hline Call the attention & 4 \\
\hline Did not answer/ did not know & 2 \\
\hline
\end{tabular}

\section{Question 3}

Why do you think the author decided to include the image in $\mathbf{A}$ and textbox images in $\mathbf{B}$ and $\mathbf{C}$ ? Use the lines below the images to write your answer.

\section{Image A}

\begin{tabular}{|l|c|}
\hline \multicolumn{1}{|c|}{ Type of answer } & Number of students \\
\hline Example for the exercise & 9 \\
\hline Interesting / less monotonous & 6 \\
\hline Call the attention & 5 \\
\hline $\begin{array}{l}\text { Children write on small pieces of } \\
\text { paper }\end{array}$ & 2 \\
\hline Did not answer/ did not know & 3 \\
\hline
\end{tabular}




\section{Image B}

\begin{tabular}{|l|c|}
\hline \multicolumn{1}{|c|}{ Type of answer } & Number of students \\
\hline Call the attention & 9 \\
\hline Beautiful and organized & 2 \\
\hline Reminder & 7 \\
\hline Exemplify & 4 \\
\hline Did not answer/ did not know & 3 \\
\hline
\end{tabular}

\section{Image C}

\begin{tabular}{|l|c|}
\hline \multicolumn{1}{|c|}{ Type of answer } & Number of students \\
\hline Exemplify & 18 \\
\hline Call the attention & 1 \\
\hline Beautiful and organized & 1 \\
\hline $\begin{array}{l}\text { Children write on small pieces of } \\
\text { paper }\end{array}$ & 1 \\
\hline Did not answer/ did not know & 4 \\
\hline
\end{tabular}

\section{Question 4}

Have you noticed the blue marker on every activity number?

Why do you think the author decided to use it?

\begin{tabular}{|l|c|}
\hline \multicolumn{1}{|c|}{ Type of answer } & Number of students \\
\hline Beautiful and colourful & 14 \\
\hline Highlight and call the attention & 7 \\
\hline Did not answer/ did not know & 4 \\
\hline
\end{tabular}




\section{Question 5}

Look at the exercise about the weather

5a. Do the drawings help you understand what to do?

\begin{tabular}{|l|c|}
\hline \multicolumn{1}{|c|}{ Type of answer } & Number of students \\
\hline Yes & 23 \\
\hline No & 1 \\
\hline Yes and no & 1 \\
\hline
\end{tabular}

If yes, How?

\begin{tabular}{|l|c|}
\hline Type of answer & Number of students \\
\hline $\begin{array}{l}\text { Facilitate the understanding of } \\
\text { exercise }\end{array}$ & 18 \\
\hline More fun / more colourful & 3 \\
\hline Draws the attention & 1 \\
\hline It is like in the news & 1 \\
\hline To save space for the author & 1 \\
\hline Did not answer/ did not know & \\
\hline
\end{tabular}

5b. Which is easier for you to understand: the drawings or the words?

\begin{tabular}{|l|c|}
\hline \multicolumn{1}{|c|}{ Type of answer } & Number of students \\
\hline Drawings & 20 \\
\hline Words & 2 \\
\hline Drawings and words & 3 \\
\hline
\end{tabular}

\section{Question 6}

Look at the picture below. Why are the bubbles used in the picture?

\begin{tabular}{|l|c|}
\hline \multicolumn{1}{|c|}{ Type of answer } & Number of students \\
\hline Thoughts & 25 \\
\hline
\end{tabular}

